ON THE RELATION OF THE PORPHYRY SERIES TO THE SKIDDAW SLATES IN THE LAKE DISTRICT.

Sir,-In the Grologicat Magazine for February last, there is a paper by Mr. J. R. Dakyns on a supposed unconformity of the Porphyry series on the Skiddaw Slates. When I read the paper I doubted very much the correctness of Mr. Dakyn's observations, and since then I have, along with my colleague (Mr. J. C. Ward, who is now surveying that part for the Government Geological Survey), examined the line of junction between the Porphyry series and Skiddaw Slates from Derwentwater to Warnscales Bottom, Buttermere, and we found that throughout the entire distance the two formations are brought against each other by faults of considerable magnitude. I cannot enter into details, which must be reserved for the Geological Survey Memoirs of that country. It is possible there may be an unconformity between the two series of beds, but the evidence of it must be sought for elsewhere than in the district described by $\mathbf{M r}$. Dakyns.

In reference to an additional Note by Mr. Dakyns on the same subject in the March number, I beg to say there is " a fault with an enormous throw" along Derwentwater.-I am, Sir, your obedient servant,

Geological Survey of England and Wales, KENDAL, June 28th, 1869.

\title{
ON MR. MURPHY'S THEORY OF THE CAUSE OF THE GLACIAL CLIMATE.
}

SIr,-In the GroL. MaG., July 1, p. 331, you report at the meeting of the Geological Society, June 9th, a paper by J. J. Murphy, Esq., F.G.S., "On the Nature and Cause of the Glacial Climate." It is stated that he agrees with me as to the Cause of Glacial Climate except in one instance. "He maintained in opposition to Mr. Croll that the glaciated hemisphere must be that in which the summer occurs in aphelion during the greatest eccentricity of the earth's orbit. $\mathrm{He}$ shewed that a cool summer had more to do with the prevalence of glacial conditions than a cold winter, and referred to several phenomena furnishing arguments in favour of his opinion."

I fear that Mr. Murphy must be resting his theory on the mistaken idea that a summer in aphelion ought to melt less snow and ice than one in perihelion. It is quite true that the louger summer in aphelion-other things being equal-is colder than the shorter one in perihelion, but the quantity of heat received from the sun is the same in both cases. Consequently the quantity of snow and ice melted ought also to be the same; for the amount melted is in proportion to the quantity of energy in the form of heat received.

It is true that with us at present less snow and ice are melted during a cold summer than during a warm one. But this is not a case in point, for during a cold summer we have less heat than during a warm summer, the length of both being the same. The coldness of the summers in this case is owing chiefly to a portion of the beat which we ought to receive from the sun being cut off by some obstructing cause. 
The reason why we have so little snow, and consequently solittle ice, in temperate regions, is not, as Mr. Murphy seems to suppose, that the heat of summer melts it all, but that there is so little to melt. And the reason why we have so little to melt is that, owing to the warmth of our winters, we have generally rain instead of snow. But if you increase the eccentricity very much, and place the winter in perihelion, we should probably have no snow whatever, and it would then, in so far as glaciation is concerned, matter very little what sort of summer we had.

But it is not correct to say that the perihelion summer of the glacial epoch must have been hot. There are physical reasons which go to prove that, notwithstanding the nearness of the sun at that season, the temperature would seldom if ever rise much above the freezing point. See Philosophical Magazine for August, 1864, pp. 134, 135 ; February, 1867, pp. 125, $126 . \quad$ JAmks Croll.

EDinguran, July 8th, 1869.

\section{DINORNIS AN AUSTRALIAN GENUS.}

SrR,-It will be interesting to your readers to know, that evidence has at length been discovered of the former existence in Continental Australia of birds of the Pleistocene New Zealand genus Dinornis.

A short time since a well was dug in that part of the Peak Downs in Queenslind (about lat. $22^{\circ} 40^{\prime} \mathrm{S}$.) between Iuord's Table Mountain and the heads of Theresa Creek, near the track from Clermont to Broad Sound.

The well passed through 30 feet of black trappean alluvial soil, so common in Australia, which rested on 150 feet of drift pebbles and boulders, on one of which (at that depth) rested a short thick femur, so filled in with mineral matter (calc spar and iron pyrites) as to give the internal structure more the appearance of a reptilian than an ornithic bone. I have never yet seen any bone in Australia so much mineralised and yet retaining its distinctive osseous features. When placed in my hands it had been already broken in two, just as a bird's bone would be likely to break. But besides this there are two crushed-in fractures of ancient date, which have broken in the surface of the bone, and if not made in the life time of the bird, were probably made by the violence of the heavy drift in which it was found.

I had an opportunity of comparing it hastily at the Australian Museum in company of Mr. Gerard Krefft, our able Curator, and was convinced of its being a bird bone allied to Dinornis, to which opinion I was afterwards led by reference to the writings of Professor Owen. Since then Mr. Krefft has conpared it with a collection sent over from New Zealand by Dr. Haast, and has been enabled to determine it to be a bone belonging to Dinornis.

I take advantage of the departure of the mail to-morrow to announce this fact, waiting for a further account of the specimen from Mr. Krefft.

The Peak Downs were discovered by Leichhardt in his famous expedition to Port Essington in 1845. 